\title{
Engineering of the human vessel wall with hair follicle stem cells in vitro
}

\author{
ZHI-CHENG XU ${ }^{1}$, QUN ZHANG ${ }^{1}$ and $\mathrm{HONG} \mathrm{LI}^{2}$ \\ ${ }^{1}$ Department of Plastic and Reconstructive Surgery, Shanghai 9th People's Hospital, Shanghai Jiaotong University \\ School of Medicine, Shanghai 200011; ${ }^{2}$ Department of Life Information and Instrument Engineering, \\ Hangzhou Electronic Science and Technology University, Hangzhou, Zhejiang 310058, P.R. China
}

Received September 28, 2015; Accepted October 11, 2016

DOI: $10.3892 / \mathrm{mmr} .2016 .6013$

\begin{abstract}
Hair follicle stem cells (HFSCs) are increasingly used as a stem cell paradigm in vascular tissue engineering due to the fact that they are a rich source of easily accessible multipotent adult stem cells. Promising results have been demonstrated with small diameter (less than $6 \mathrm{~mm}$ ) tissue engineered blood vessels under low blood pressure, however engineering large vessels ( $>6 \mathrm{~mm}$ in diameter) remains a challenge due to the fact it demands a higher number of seed cells and higher quality biomechanical properties. The aim of the current study was to engineer a large vessel $(6 \mathrm{~mm}$ in diameter) with differentiated smooth muscle cells (SMCs) induced from human (h)HFSCs using transforming growth factor- $\beta 1$ and platelet-derived grow th factor $\mathrm{BB}$ in combination with low-serum culture medium. The cells were seeded onto polyglycolic acid and then wrapped around a silicone tube and further cultured in vitro. A round vessel wall was formed subsequent to 8 weeks of culture. Histological examination indicated that layers of smooth muscle-like cells and collagenous fibres were oriented in the induced group. In contrast, disorganised cells and collagenous fibres were apparent in the undifferentiated group. The approach developed in the current study demonstrated potential for constructing large muscular vessels with differentiated SMCs induced from hHFSCs.
\end{abstract}

\section{Introduction}

Cardiovascular diseases remain a significant health and socioeconomic burden in developed countries (1). Surgical bypass with an autologous vein remains the primary treatment (2), however, a usable vascular graft is often absent due to limited sources and

Correspondence to: Professor Qun Zhang, Department of Plastic and Reconstructive Surgery, Shanghai 9th People's Hospital, Shanghai Jiaotong University, School of Medicine, 639 Zhi Zao Ju Road, Shanghai 200011, P.R. China

E-mail: zhangqunmd@163.com

Key words: vascular tissue engineering, hair follicle stem cells, smooth muscle cells donor site morbidity. In addition, current widely used synthetic materials have several limitations including immunological and thrombotic complications. Furthermore, these vascular grafts are usually non-degradable and lack growth potential $(3,4)$.

The development of tissue engineering technology is promising for potential improvement over currently used synthetic grafts. A blood vessel made of autologous cells and a biocompatible scaffold with the potential to remodel, repair and grow would be a major therapeutic advance (5). Promising results have been demonstrated with small diameter $(<6 \mathrm{~mm})$ tissue engineered blood vessels (TEBVs) under low blood pressure (6-8), however, few studies have focused on cases with larger vessels ( $>6 \mathrm{~mm}$ in diameter), which demand an increased number of seed cells and improved biomechanical properties.

However, tissue engineering approaches are limited by the large number of cells that must be obtained for regenerative medicine. Stem cells are promising cell sources with increased proliferation and broad differentiation capacity, making them suitable for the preparation of TEBVs (9-11). Although several types of stem and progenitor cells have been investigated for their potential as sources of seed cells in vascular tissue engineering (12-16), hair follicles are increasingly used for stem cell research due to the fact that they are a rich source of easily accessible multipotent adult stem cells. Hair follicle stem cells (HFSCs) have been demonstrated to possess osteogenic, adipogenic, chondrogenic, neurogenic and myogenic lineage differentiation potential (7,17-19).

In a previous study, human HFSCs (hHFSCs) were successfully induced to differentiate into functional smooth muscle cells (SMCs) by transforming growth factor- $\beta 1$ (TGF- $\beta 1$ ) and platelet-derived growth factor BB (PDGF-BB) in combination with low-serum culture medium (20). The aim of the present study was to engineer a large vessel (6 $\mathrm{mm}$ in diameter) using induced hHFSCs and polyglycolic acid (PGA) with 8 weeks of in vitro culture. The rapid degradation of the PGA prevents the accumulation of degraded fragments in vivo. The culture system used indicated potential to construct large muscular vessels with differentiated SMCs induced from hHFSCs.

\section{Materials and methods}

Isolation and culture of hHFSCs. hHFSCs were obtained from human scalp tissue from healthy adult patients (average age, 
30 years) undergoing cosmetic plastic surgery, as described previously (20). All protocols for human tissue handling were approved by the Research Ethical Committee of Shanghai 9th People's Hospital, and written informed consent was obtained from the patients. hHFSCs at the second passage were used in the subsequent study. The hHFSCs were characterised by determining their CD marker profile (K15, K19 and integrin $\beta 1$ ) and their ability to differentiate into osteogenic, adipogenic and chondrogenic lineages (data not shown), as reported previously $(21,22)$.

Induction of SM differentiation. As previously reported (20), hHFSCs reaching subconfluence were cultured in low-glucose Dulbecco's modified Eagle's medium (LG-DMEM; Gibco; Thermo Fisher Scientific, Inc., Waltham, MA, USA) containing $10 \%$ foetal bovine serum (FBS; GE Healthcare Life Sciences, Logan, UT, USA) supplemented with $5 \mathrm{ng} / \mathrm{ml}$ recombinant human TGF- $\beta 1$ (R\&D Systems, Inc., Minneapolis, MN, USA) and $10 \mathrm{ng} / \mathrm{ml}$ recombinant human PDGF-BB (R\&D Systems, Inc.) with $1 \%$ FBS. DMEM supplemented with $1 \%$ FBS was defined as the basal medium (BM). Human umbilical artery SMCs (hUASMCs) were obtained from ScienCell Research Laboratories (Carlsbad, CA, USA) and used as the positive control. The culture media were changed every 2 days. Cell characterisation and functional evaluation (data not shown) were performed subseqeuent to 8 days of culture as described previously (20).

Culture of hHFSC-PGA sheets in dishes. In the current study, $35 \mathrm{mg}$ unwoven PGA fibres (Albany International Research Co., Albany, NY, USA) were constructed into an approximately $35 \times 80 \times 2 \mathrm{~mm}$ mesh. The scaffold was first soaked in 75\% ethanol (Sigma-Aldrich; Merck Millipore, Darmstadt, Germany) for $2 \mathrm{~h}$. Subsequently, it was washed three times with phosphate-buffered saline and incubated in DMEM for $10 \mathrm{~min}$. The medium was removed, and the scaffold was incubated in an incubator (Binder $\mathrm{GmbH}$, Tuttlingen, German) at $37^{\circ} \mathrm{C}$ prior to use. Differentiated and undifferentiated hHFSCs $\left(6 \times 10^{7}\right)$ were each evenly seeded onto the PGA mesh in 100-mm culture dishes (Falcon; BD Biosciences, San Jose, CA, USA). To accomplish the complete adhesion of the hHFSCs to the fibres, the cell-scaffold constructs were then maintained in the incubator at $37^{\circ} \mathrm{C}$ with $95 \%$ humidity and $5 \% \mathrm{CO}_{2}$ for approximately $4 \mathrm{~h}$. Thereafter, sufficient induced culture medium or BM was added to the two dishes to cover the constructs. The cell-PGA sheets were incubated at $37^{\circ} \mathrm{C}$ for another 5 days prior to use.

Induced culture in dishes. Subsequent to culture in dishes for 5 days, the cell-PGA sheets were wrapped around the silicone tubes and fixed by biodegradable sutures (Ethicon, Inc., Somerville, NJ, USA) for another 8 weeks of culture. The culture media was changed twice a week. The cell-PGA constructs cultured in BM were used as the controls.

Histological analysis. Subsequent to 8 weeks of culture, the engineered vessel walls were harvested, fixed in $10 \%$ formalin (Sigma-Aldrich; Merck Millipore) and embedded in paraffin (Sigma-Aldrich; Merck Millipore). Following this, they were sequentially cut into sections of $4 \mathrm{~mm}$ thickness.
The sections were then tested with haematoxylin and eosin or Masson's trichrome and Gömöri staining (all stains were from Sigma-Aldrich; Merck Millipore).

Hydroxyproline assay. For hydroxyproline assessment, the vessel wall was dried and weighed. The total hydroxyproline content of each vessel was determined by a colorimetric assay described by Reddy and Ewemeka (23). In the current study, a Sigma-MAK008, Hydroxyproline Assay Kit (Sigma-Aldrich; Merck Millipore) and a Genesys 20 Spectrophotometer (Z376027; Sigma-Aldrich; Merck Millipore) were used. Normal human saphenous vein with a diameter of $4 \mathrm{~mm}$ served as the control. The veins were obtained from human adult patients undergoing cardiovascular surgery with autologous vein graft. The residual saphenous veins were contributed for future experimental studies, written informed consent was obtained from the patients. All protocols for human tissue handling were approved by the Research Ethical Committee of Shanghai 9th People's Hospital.

Statistical analysis. Each experiment was repeated a minimum of three times. The results were expressed as the mean \pm standard deviation. Significant differences were measured using Student's t-test. $\mathrm{P}<0.05$ was considered to indicate a statistically significant differences. All of the statistical analyses were performed using SPSS software, version 16 (SPSS, Inc., Chicago, IL, USA).

\section{Results}

Culture of hHFSC-PGA constructs in dishes. Subsequent to $24 \mathrm{~h}$ of culture, the cells began to spread and extended along the length of the fibres. Following an additional 5 days of culture in the dishes, a cell-PGA sheet had formed (Fig. 1A). Micrographs indicated that abundant hHFSCs had adhered to the PGA fibres, with secreted extracellular matrix (ECM) filling the spaces between the fibres (Fig. 1B).

Induced culture in dishes. The hHFSC-PGA constructs were incubated in culture dishes for 8 weeks subsequent to being wrapped around silicone tubes (Fig. 2). In the induced group, the constructs demonstrated a glossy and tubular structure with a round lumen $6 \mathrm{~mm}$ in diameter (Fig. 3A). In contrast, the vessel walls in the static culture group exhibited a collapsed lumen and rough surface (Fig. 3B).

Histological observation. Subsequent to 8 weeks of further induced culture in vitro, several smooth muscle-like cells and few collagenous fibres were observed by histological examination (Fig. 4A and B). The PGA fibres had degraded completely, and few elastic fibres were observed at this time (Fig. 4C). In contrast, disorganised cells, randomly collagenous fibres and small elastic fibres were observed in the undifferentiated group (Fig. 4D-F). The above results were further confirmed by immunohistochemical staining for smooth muscle $\alpha$-actin and calponin (data not shown), using the hUASMCs as a positive control (Fig. 4G-I).

Hydroxyproline assay. The hydroxyproline content was significantly higher $(\mathrm{P}<0.05)$ in the induced group than in the 
A

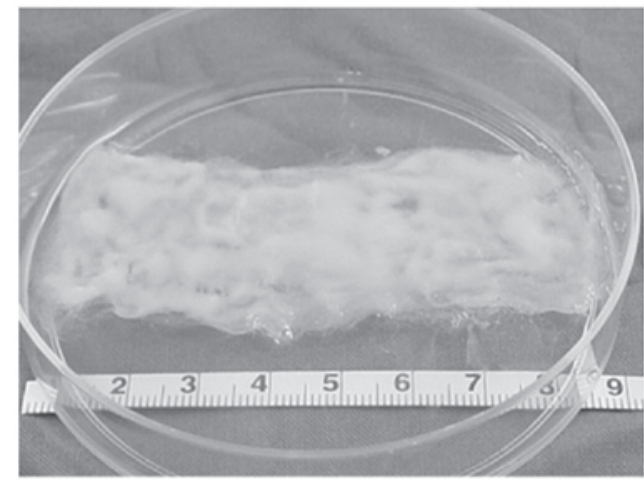

B

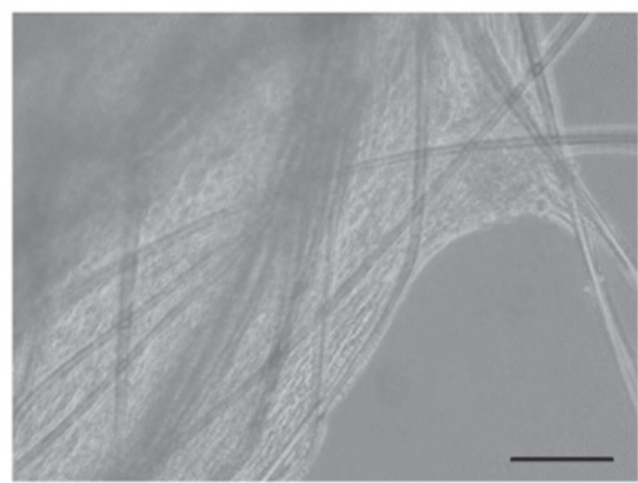

Figure 1. Cell-scaffold constructs cultured in dishes. (A) Gross view of the production of extracellular matrix by hHFSCs on PGA fibers. (B) At 5 days, microscopic observation demonstrated that sufficient hHFSCs had adhered to the PGA fibers with secreted extracellular matrix filling the space between the fibers. Scale bar, $100 \mu \mathrm{m}$. hHFSC, human hair follicle stem cell; PGA, polyglycolic acid.

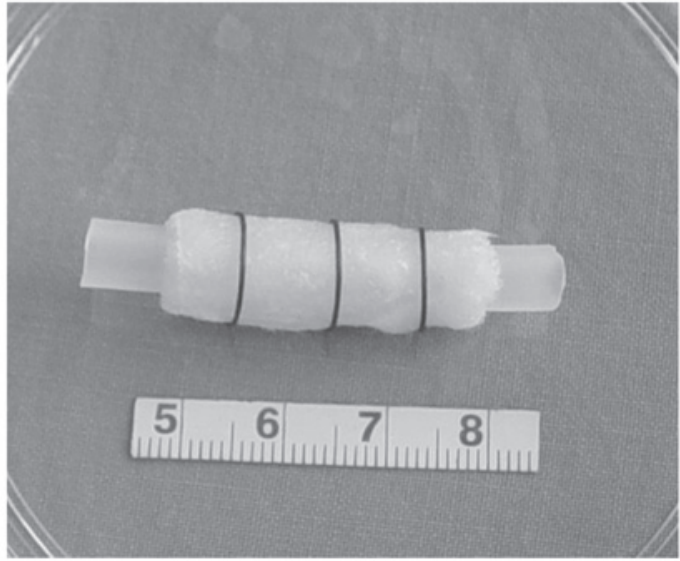

Figure 2. Gross view of the cell-polyglycolic acid sheet wrapped around a silicone tube in the culture dish, secured by biodegradable sutures.

control group at the same time points (Fig. 5). In addition, the hydroxyproline concentration in the induced group reached approximately $65 \%$ of that in the hUASMCs.

\section{Discussion}

hHFSCs have been previously successfully isolated from patients, expanded, differentiated and used to construct autologous tissue (22,24-26). This method eliminates the need for immunosuppressants and mitigates the risk of teratoma formation associated with embryonic stem cells and induced pluripotent stem cells (27). In a previous study, hHFSCs were induced to differentiate into functional SMCs by TGF- $\beta 1$ and PDGF-BB in combination with low-serum culture medium (20). In the current study, a large diameter vessel wall was engineered using the aforementioned differentiated hHFSCs and PGA unwoven fibre mesh in vitro. Subsequent to culture, the newly formed tissues exhibited SM-like characteristics, including morphological performance, the expression of SM cell-specific markers (SM $\alpha$-actin and calponin) and appropriate hydroxyproline content. These results demonstrated that hHFSCs may be utilised as a potential cell source for the tissue engineering of SMs, particularly that of the large diameter aorta.

Tissue engineering predominantly focuses on the incorporation of isolated cells with supporting scaffolds (28). An
A
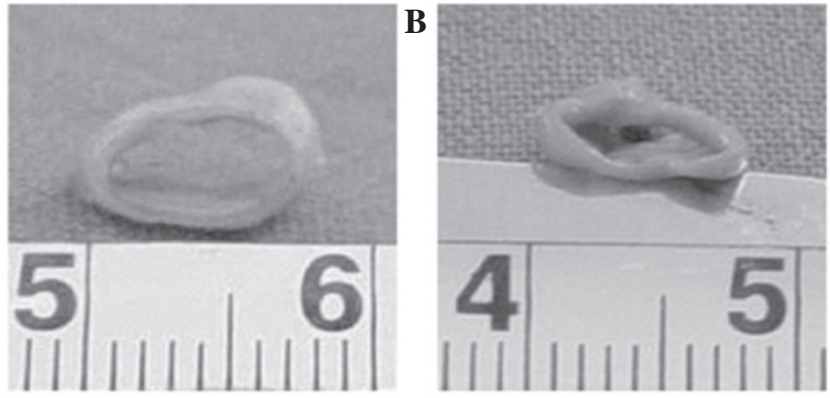

Figure 3. Gross view of the engineered vessels. (A) Vessel walls with round lumen ( $6 \mathrm{~mm}$ in diameter) are formed after 8 weeks of culture with induced media. (B) Vessel walls with a collapsed lumen and rough surface are observed after culture in basal medium.

optimal scaffold degrades proportionally with tissue regeneration to be gradually replaced by newly formed functional tissue, and it supports cellular adhesion and collagenous matrix deposition (29). In vascular tissue engineering, the scaffold should reflect the biomechanical properties of blood vessels and serve as a platform for cell attachment and proliferation (30). It should be non-thrombogenic, non-immunogenic, biocompatible, haemocompatible, biodegradable and elastic $(31,32)$. Furthermore, it should also control the extent and the strength of cell adhesion, proliferation, differentiation and maturation to achieve the desired phenotype and proper function (33). PGA is one of the most extensively used polymer scaffold materials in the engineering of numerous types of tissues, including blood vessels. It is a polyester that undergoes rapid degradation via hydrolysis of ester bonds, leaving behind glycolic acid and is further catabolised into water and carbon dioxide (34). The mechanical properties and degradation profile of PGA make it an attractive candidate for vascular tissue engineering (35). Numerous studies have demonstrated the successful use of PGA scaffolds for constructing vascular grafts $(7,31,32,34,36)$. In the current study, cells in the experimental group were demonstrated to possess good proliferative ability and ECM secretion on PGA.

In the histological examination, it was identified that the content and distribution of SMCs and elastin in the experimental group were not as dense as those in normal 
A

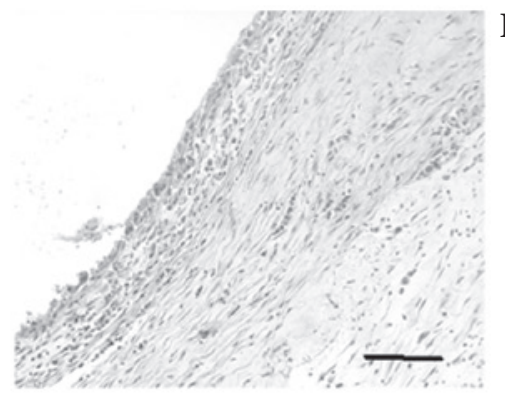

D

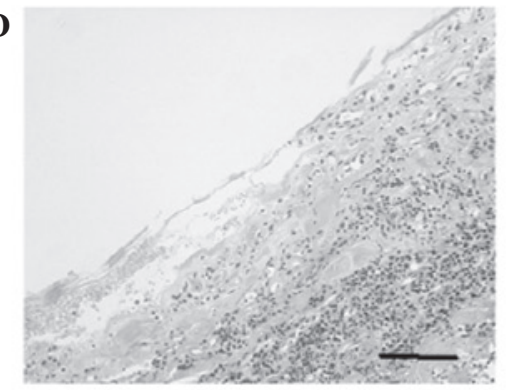

G

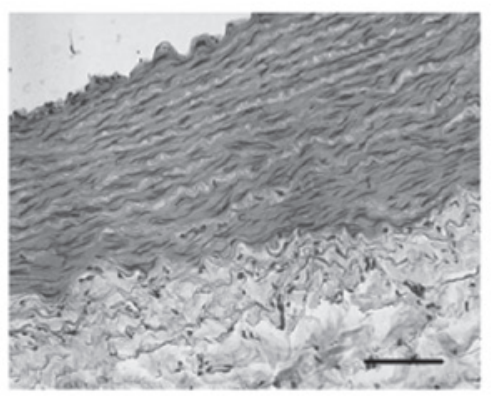

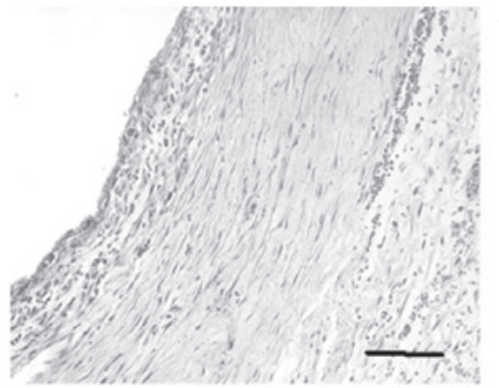

E

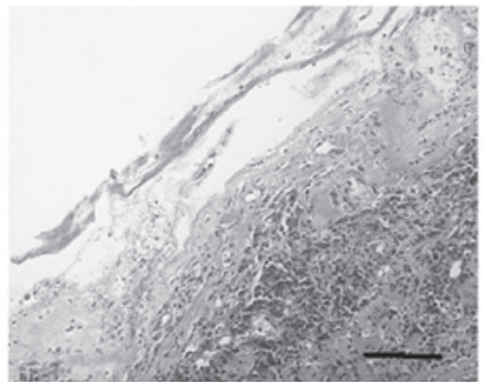

$\mathbf{H}$

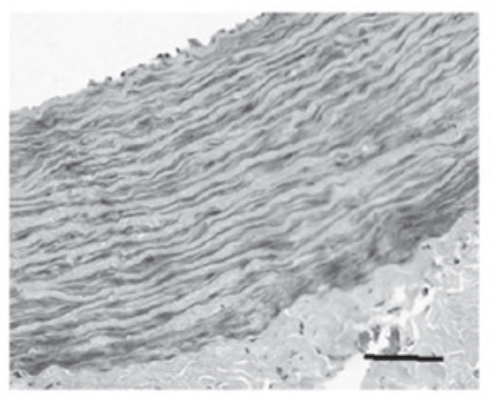

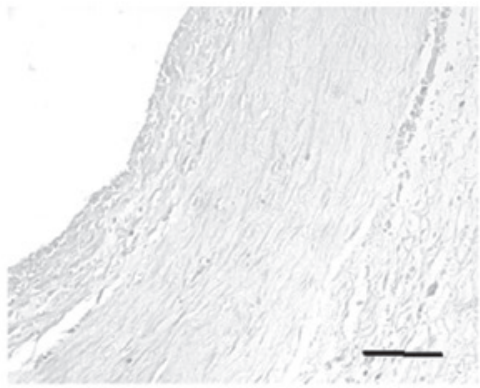

F

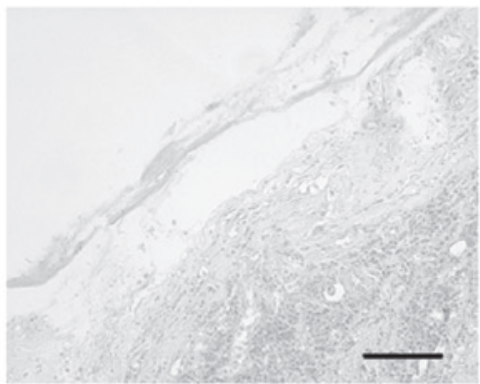

I

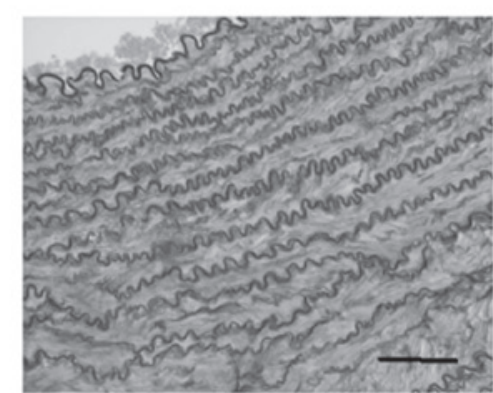

Figure 4. Histology of the engineered vessel walls after 8 weeks of culture with (A-C) or without (D-F) induced media. (A) Hematoxylin and eosin staining shows several layers of smooth muscle-like fibers in induced groups. Staining with (B) Masson's trichrome and (D) Gömöri trichrome indicates few collagen and elastic fibers in the experimental groups. By contrast, in the control group disorganized distributed cells were observed in (D) hematoxylin and eosin staining. Meanwhile, randomly collagenous fibers were found in (E) Masson's trichrome staining and few elastic fibers were shown in (F) Gömöri trichrome staining. Native canine abdominal arteries are presented for reference. It demonstrated layered and organized cells of the vessel walls in (G) hematoxylin and eosin staining. Dense collagenous fibers and much elastic fibers were shown in (H) Masson's trichrome staining and (I) Gömöri trichrome staining respectively.. Scale bars, $50 \mu \mathrm{m}$.

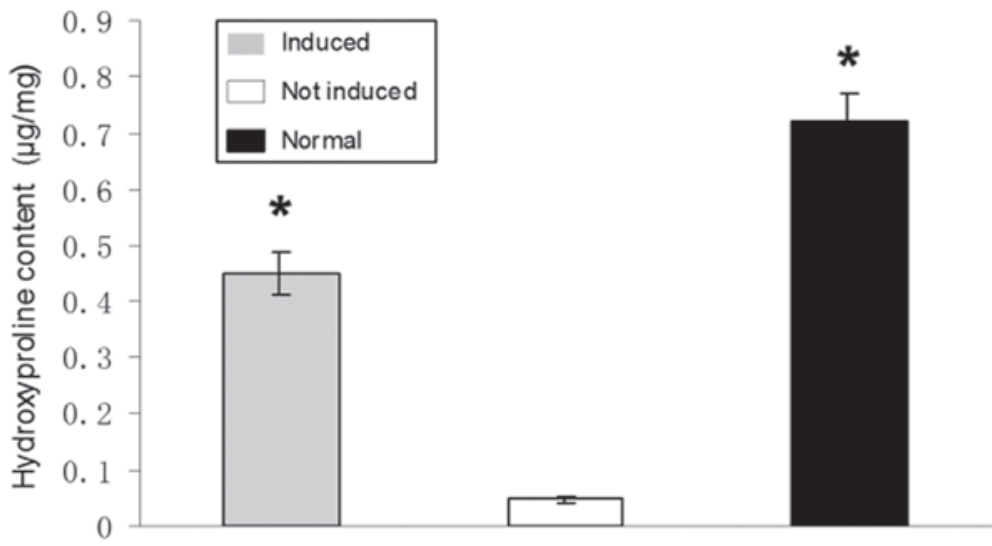

Figure 5. The amount of hydroxyproline in the induced group is higher than that in the control (non-induced) group and is approximately $65 \%$ of that of the normal vessel subsequent to 8 weeks of induced culture. Four samples from each group were measured in each of the above experiments. Data are presented as the mean \pm standard deviation. ${ }^{*} \mathrm{P}<0.05$ vs. control group.

blood vessels. Normal blood vessels have been demonstrated to develop under the influence of the mechanical force of blood, which is an important physiological component of the environment experienced by cells: It promotes the circumferential orientation of the cells in addition to the deposition of the extracellular matrix, and it likely contributes to the 
survival of implanted substitutes (36). It is suggested that dynamic culturing is important in vascular tissue engineering. In vitro investigations have demonstrated that low shear stress induces SMC proliferation (37-40) and promotes collagen alignment (41) and that cyclic stretching induces clear alterations in the SMC phenotype, function and gene expression $(42,43)$. SMCs use multiple sensing mechanisms to perceive the mechanical stimulus generated from pulsatile stretching and transduce it into intracellular signals. This results in the modulation of gene expression and cellular functions including proliferation, apoptosis, migration and remodelling (44-49). Therefore, a bioreactor, which is currently is under development, may be used in future studies to mimic the physiological environment of the arterial vessel wall.

In conclusion, a large vessel (6 $\mathrm{mm}$ in diameter) was constructed using PGA seeded with hHFSCs in vitro. Induced culture constructs exhibited improved performance histologically and in hydroxyproline content when compared with constructs of the undifferentiated group. Further research focused on dynamic culturing of the constructs and further seeding of endothelial cells on the surface of the lumen to engineer composite vascular conduits is required, in order to progress in this area of bio-engineering.

\section{Acknowledgements}

The present study was supported by the National Natural Science Foundation of China (grant no. 81000842). The authors would additionally like to thank Mr Demin Ying, Mrs Lijuan Zong and Mr Bing Zhong for their technical assistance.

\section{References}

1. Kohn JC, Lampi MC and Reinhart-King CA: Age-related vascular stiffening: Causes and consequences. Front Genet 6: $112,2015$.

2. Lee AY, Mahler N, Best C, Lee YU and Breuer CK: Regenerative implants for cardiovascular tissue engineering. Transl Res 163 321-341, 2014.

3. Kurobe H, Maxfield MW, Breuer CK and Shinoka T: Concise review: Tissue-engineered vascular grafts for cardiac surgery: Past, present, and future. Stem Cells Transl Med 1: 566-571, 2012.

4. Nemeno-Guanzon JG, Lee S, Berg JR, Jo YH, Yeo JE, Nam BM, Koh YG and Lee JI: Trends in tissue engineering for blood vessels. J Biomed Biotechnol 2012: 956345, 2012.

5. Teebken $\mathrm{OE}$ and Haverich A: Tissue engineering of small diameter vascular grafts. Eur J Vasc Endovasc Surg 23: 475-485, 2002.

6. Wang Y, Hu J, Jiao J, Liu Z, Zhou Z, Zhao C, Chang LJ, Chen YE, Ma PX and Yang B: Engineering vascular tissue with functional smooth muscle cells derived from human iPS cells and nanofibrous scaffolds. Biomaterials 35: 8960-8969, 2014.

7. Wang C, Cen L, Yin S, Liu Q, Liu W, Cao Y and Cui L: A small diameter elastic blood vessel wall prepared under pulsatile conditions from polyglycolic acid mesh and smooth muscle cells differentiated from adipose-derived stem cells. Biomaterials 31 621-630, 2010.

8. Wilhelmi M, Jockenhoevel S and Mela P: Bioartificial fabrication of regenerating blood vessel substitutes: Requirements and current strategies. Biomed Tech (Berl) 59: 185-195, 2014

9. Nerem RM and Seliktar D: Vascular tissue engineering. Annu Rev Biomed Eng 3: 225-243, 2001.

10. Naito Y, Shinoka T, Duncan D, Hibino N, Solomon D, Cleary M, Rathore A, Fein C, Church S and Breuer C: Vascular tissue engineering: Towards the next generation vascular grafts. Adv Drug Deliv Rev 63: 312-323, 2011.
11. Khait L and Birla RK: Bypassing the patient: Comparison of biocompatible models for the future of vascular tissue engineering. Cell Transplant 21: 269-283, 2012.

12. Zhu GC, Gu YQ, Geng X, Feng ZG, Zhang SW, Ye L and Wang ZG: Experimental study on the construction of small three-dimensional tissue engineered grafts of electrospun poly- $\varepsilon$-caprolactone. J Mater Sci Mater Med 26: 112, 2015.

13. Koobatian MT, Liang MS, Swartz DD and Andreadis ST: Differential effects of culture senescence and mechanical stimulation on the proliferation and leiomyogenic differentiation of MSC from different sources: Implications for engineering vascular grafts. Tissue Eng Part A 21: 1364-1375, 2015.

14. G N, Tan A, Gundogan B, Farhatnia Y, Nayyer L, Mahdibeiraghdar S, Rajadas J, De Coppi P, Davies AH and Seifalian AM: Tissue engineering vascular grafts a fortiori: Looking back and going forward. Expert Opin Biol Ther 15: 231-244, 2015.

15. Sundaram S, One J, Siewert J, Teodosescu S, Zhao L, Dimitrievska S, Qian H, Huang AH and Niklason L: Tissue-engineered vascular grafts created from human induced pluripotent stem cells. Stem Cells Transl Med 3: 1535-1543, 2014.

16. Rammal H, Harmouch C, Lataillade JJ, Laurent-Maquin D, Labrude P, Menu P and Kerdjoudj H: Stem cells: A promising source for vascular regenerative medicine. Stem Cells Dev 23: 2931-2949, 2014

17. Heydarkhan-Hagvall S, Schenke-Layland K, Yang JQ, Heydarkhan S, Xu Y, Zuk PA, MacLellan WR and Beygui RE: Human adipose stem cells: A potential cell source for cardiovascular tissue engineering. Cells Tissues Organs 187: 263-274, 2008.

18. Harris LJ, Abdollahi H, Zhang P, McIlhenny S, Tulenko TN and DiMuzio PJ: Differentiation of adult stem cells into smooth muscle for vascular tissue engineering. J Surg Res 168: 306-314, 2011.

19. Hsu YC, Pasolli HA and Fuchs E: Dynamics between stem cells, niche, and progeny in the hair follicle. Cell 144: 92-105, 2011

20. Xu ZC, Zhang Q and Li H: Human hair follicle stem cell differentiation into contractile smooth muscle cells is induced by transforming growth factor- $\beta 1$ and platelet-derived growth factor BB. Mol Med Rep 8: 1715-1721, 2013.

21. Jahoda CA, Whitehouse J, Reynolds AJ and Hole N: Hair follicle dermal cells differentiate into adipogenic and osteogenic lineages. Exp Dermatol 12: 849-859, 2003.

22. Yu H, Fang D, Kumar SM, Li L, Nguyen TK, Acs G, Herlyn M and Xu X: Isolation of a novel population of multipotent adult stem cells from human hair follicles. Am J Pathol 168: 1879-1888, 2006.

23. Reddy GK and Ewemeka CS: A simplified method for the analysis of hydroxyproline in biological tissues. Clin Biochem 29: 225-229, 1996

24. Naito Y, Rocco K, Kurobe H, Maxfield M, Breuer C and Shinoka T: Tissue engineering in the vasculature. Anat Rec (Hoboken) 297: 83-97, 2014.

25. Drewa T, Joachimiak R, Kaznica A, Sarafian V and Pokrywczynska M: Hair stem cells for bladder regeneration in rats: Preliminary results. Transplant Proc 41: 4345-4351, 2009.

26. Lin H, Liu F, Zhang C, Zhang Z, Kong Z, Zhang X and Hoffman RM: Characterization of nerve conduits seeded with neurons and Schwann cells derived from hair follicle neural crest stem cells. Tissue Eng Part A 17: 1691-1698, 2011.

27. Jiang Y, Jahagirdar BN, Reinhardt RL, Schwartz RE, Keene CD, Ortiz-Gonzalez XR, Reyes M, Lenvik T, Lund T, Blackstad M, et al: Pluripotency of mesenchymal stem cells derived from adult marrow. Nature 418: 41-49, 2002

28. DiMuzio P and Tulenko T: Tissue engineering applications to vascular bypass graft development: The use of adipose-derived stem cells. J Vasc Surg 45 (Suppl A): A99-A103, 2007.

29. Collins MN and Birkinshaw C: Hyaluronic acid based scaffolds for tissue engineering-a review. Carbohydr Polym 92: 1262-1279, 2013.

30. Lee SJ, Liu J, Oh SH, Soker S, Atala A and Yoo JJ: Development of a composite vascular scaffolding system that withstands physiological vascular conditions. Biomaterials 29: 2891-2898, 2008.

31. Pankajakshan D and Agrawal DK: Scaffolds in tissue engineering of blood vessels. Can J Physiol Pharmacol 88: 855-873, 2010.

32. Gui L, Zhao L, Spencer RW, Burghouwt A, Taylor MS Shalaby SW and Niklason LE: Development of novel biodegradable polymer scaffolds for vascular tissue engineering. Tissue Eng Part A 17: 1191-1200, 2011.

33. Bačáková L, Novotná K and Pařízek M: Polysaccharides as cell carriers for tissue engineering: The use of cellulose in vascular wall reconstruction. Physiol Res 63 (Suppl 1): S29-S47, 2014. 
34. Thottappillil $\mathrm{N}$ and Nair PD: Scaffolds in vascular regeneration: Current status. Vasc Health Risk Manag 11: 79-91, 2015.

35. Dong Y, Yong T, Liao S, Chan CK, Stevens MM and Ramakrishna S: Distinctive degradation behaviors of electrospun polyglycolide, poly (dl-lactide-co-glycolide), and poly (1-Lactide-co-epsilon-caprolactone) nanofibers cultured with/without porcine smooth muscle cells. Tissue Eng Part A 16: 283-298, 2010.

36. Xu ZC, Zhang Q and Li H: An elastic large muscular vessel wall engineered with bone marrow-derived cells under pulsatile stimulation in a bioreactor. Mol Med Rep 12: 6005-6012, 2015.

37. Sterpetti AV, Cucina A, Santoro L, Cardillo B and Cavallaro A Modulation of arterial smooth muscle cell growth by haemodynamic forces. Eur J Vasc Surg 6: 16-20, 1992.

38. Sho M, Sho E, Singh TM, Komatsu M, Sugita A, Xu C, Nanjo H, Zarins CK and Masuda H: Subnormalshear stress-induced intimal thickening requires medial smooth muscle cell proliferation and migration. Exp Mol Pathol 72: 150-160, 2002.

39. Palumbo R, Gaetano C, Antonini A, Pompilio G, Bracco E, Rönnstrand L, Heldin CH and Capogrossi MC: Different effects of high and low shear stress on platelet-derived growth factor isoform release by endothelial cells: Consequences for smooth muscle cell migration. Arterioscler Thromb Vasc Biol 22: 405-411, 2002.

40. Qi YX, Qu MJ, Long DK, Liu B, Yao QP, Chien S and Jiang ZL: Rho-GDP dissociation inhibitor alpha downregulated by low shear stress promotes vascular smooth muscle cell migration and apoptosis: A proteomic analysis. Cardiovasc Res 80: 114-122, 2008.

41. Ng CP, Hinz B and Swartz MA: Interstitial fluid flow induces myofibroblast differentiation and collagen alignment in vitro. J Cell Sci 118: 4731-4739, 2005.
42. Halka AT, Turner NJ, Carter A, Ghosh J, Murphy MO, Kirton JP, Kielty CM and Walker MG: The effects of stretch on vascular smooth muscle cell phenotype in vitro. Cardiovasc Pathol 17: 98-102, 2008

43. Jakkaraju S, Zhe X and Schuger L: Role of stretch in activation of smooth muscle cell lineage. Trends Cardiovasc Med 13: 330-335, 2003

44. Haga JH, Li YS and Chien S: Molecular basis of the effects of mechanical stretch on vascular smooth muscle cells. J Biomech 40: 947-960, 2007.

45. Standley PR, Cammarata A, Nolan BP, Purgason CT and Stanley MA: Cyclic stretch induces vascular smooth muscle cell alignment via NO signaling. Am J Physiol Heart Circ Physiol 283: H1907-H1914, 2002.

46. Zhu JH, Chen CL, Flavahan S, Harr J, Su B and Flavahan NA: Cyclic stretch stimulates vascular smooth muscle cell alignment by redox-dependent activation of Notch3. Am J Physiol Heart Circ Physiol 300: H1770-H1780, 2011.

47. Chapman GB, Durante W, Hellums JD and Schafer AI: Physiological cyclic stretch causes cell cycle arrest in cultured vascular smooth muscle cells. Am J Physiol Heart Circ Physiol 278: H748-H754, 2000.

48. Iwasaki H, Yoshimoto T, Sugiyama T and Hirata Y: Activation of cell adhesion kinase beta by mechanical stretch in vascular smooth muscle cells. Endocrinology 144: 2304-2310, 2003.

49. Qiu J, Zheng Y, Hu J, Liao D, Gregersen H, Deng X, Fan Y and Wang G: Biomechanical regulation of vascular smooth muscle cell functions: From in vitro to in vivo understanding. J R Soc Interface 11: 20130852, 2013. 